\title{
New records of Heteroceridae (Coleoptera) from Ethiopia
}

\author{
Alexey S. SAZHNEV and Alexander A. PROKIN \\ Papanin Institute for Biology of Inland Waters of the Russian Academy of Sciences, Borok, 152742 Russia; \\ e-mails:sazh@list.ru,prokina@mail.ru
}

\begin{abstract}
New faunistic records of Heteroceridae from Ethiopia from the rivers Gumara and Rib are provided. Two species shown for the first time in the country: Heterocerus atroincertus Charpentier, 1965 and Heterocerus tibesticola Charpentier, 1964 increase the number of mud-beetles of Ethiopian fauna to seven species.
\end{abstract}

Key words: beetles, Heterocerus, Afrotropical region, faunistic, new records

\section{INTRODUCTION}

The beetle family Heteroceridae is world-wide distributed (except Antarctica) (King \& Lago 2012, Taşar \& Mascagni 2014) and represented by 341 described species (including extinct ones) from 5 recent, and 1 extinct genus (Sazhnev 2018). Adults and larvae of Heteroceridae construct tunnels in wet sand and soil at the edges of streams, rivers, lakes and ponds, and in brackish mud flats (Mascagni 1995, Taşar 2014, Vanin et al. 2016). Five species of Heteroceridae were recorded from Ethiopia: Heterocerus abyssinicus Mamitza, 1930, H. elongatus Grouvelle, 1896, H. hardei Mascagni, 1988, H. incertus Grouvelle, 1896, and H. medius Charpentier, 1965 (Mamitza 1930, Charpentier 1965, Mascagni 1988, Mascagni \& Monte 2003, 2009).

\section{MATERIAL AND METHODS}

The material has been collected by Alexander A. Prokin during investigations of the Joint Ethiopian-Russian Biological Expedition in October, 2018. Specimens of Heteroceridae were collected using trampling and flushing along rivers banks. All specimens were collected at a distance less than one meter from water edge (Figs 4-5) on sandy-gravel substrate together with Carabidae: Dyschiriini and Hydrophilidae (Coleoptera).

All collected beetles are stored in the Collection of aquatic invertebrates of the Papanin Institute for Biology of Inland Waters of the Russian Academy of Sciences (Yaroslavl Oblast, Borok, Russia, IBIW RAS). For preliminary identification of Heterocerus species we used key of Charpentier (1965).

Photographs of the beetles and the localities were taken using Olympus GT-5 digital camera. Images were generated and enhanced by using PHOTOSHOP ${ }^{\circledR}$

\section{RESULTS}

Family Heteroceridae MacLeay, 1825

Genus Heterocerus Fabricius, 1792 


\section{Heterocerus atroincertus Charpentier, 1965}

(Fig. 1)

Material examined. 1ðَ, Ethiopia: Amhara Region, Gumara River, $11^{\circ} 47^{\prime} 14.6^{\prime \prime} \mathrm{N}$ 370'45.8"E (Fig. 4), 10 Oct 2018, coll. A. A. Prokin, IBIW RAS).

Distribution. Botswana, Kenya, Malawi, Mozambico, South Africa, Tanzania, Zaire, Zambia, Zimbabwe (Mascagni \& Monte 2009, Mascagni 2012).

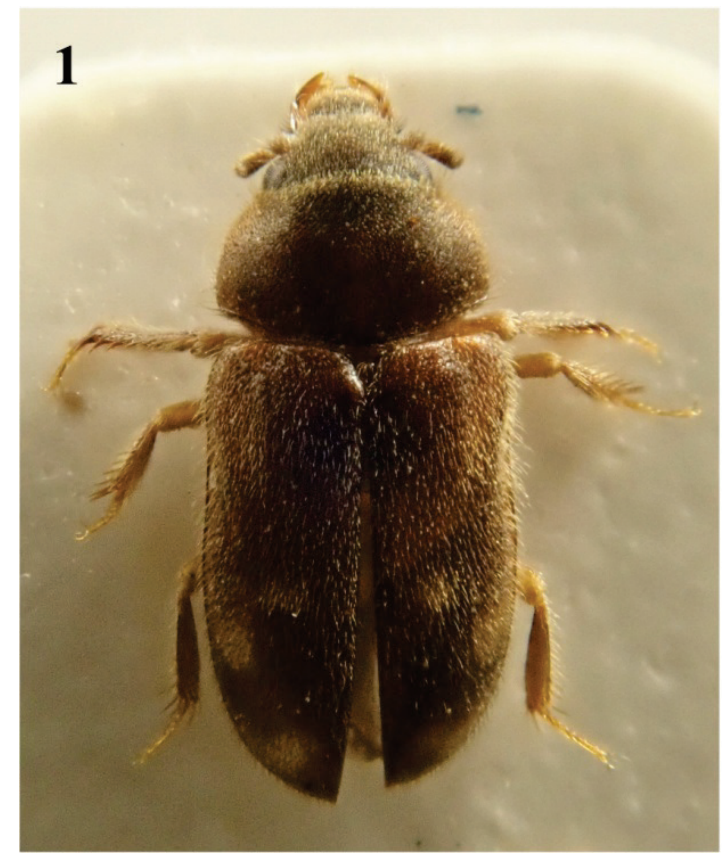

Fig. 1. Heterocerus atroincertus Charpentier, 1965, male (Gumara River).

\section{Heterocerus tibesticola Charpentier, 1964}

(Figs 2-3)

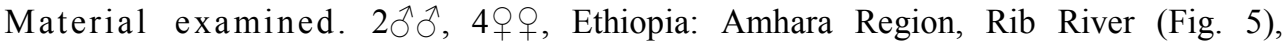
$12^{\circ} 02^{\prime} 54.6^{\prime \prime} \mathrm{N}, 37^{\circ} 58^{\prime} 53.3^{\prime \prime E}, 8$ Oct 2018, coll. A. A. Prokin, IBIW RAS; $5 \partial^{\lambda}, 2+\circ$, Amhara

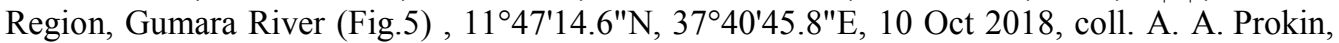
IBIW RAS.

Distribution. Chad, Yemen (Charpentier, 1964, 1965).

\section{COMMENTS}

The fauna of the variegated mud-loving beetles of Ethiopia is still poorly known and now includes 7 species with these two new records. Based on data of Mascagni and Monte (2009), about 20 species of Heteroceridae are recorded for North Africa (Palearctic part) and about 50 for Afrotropical region. The following numbers of species are known from the countries bordering Ethiopia: Kenya - 10 species, Sudan - 6, Somalia - 5, Eritrea - 3; data for South Sudan and Djibouti do not exist. In territory of Ethiopia at least 9 more heterocerid species should be expected. 

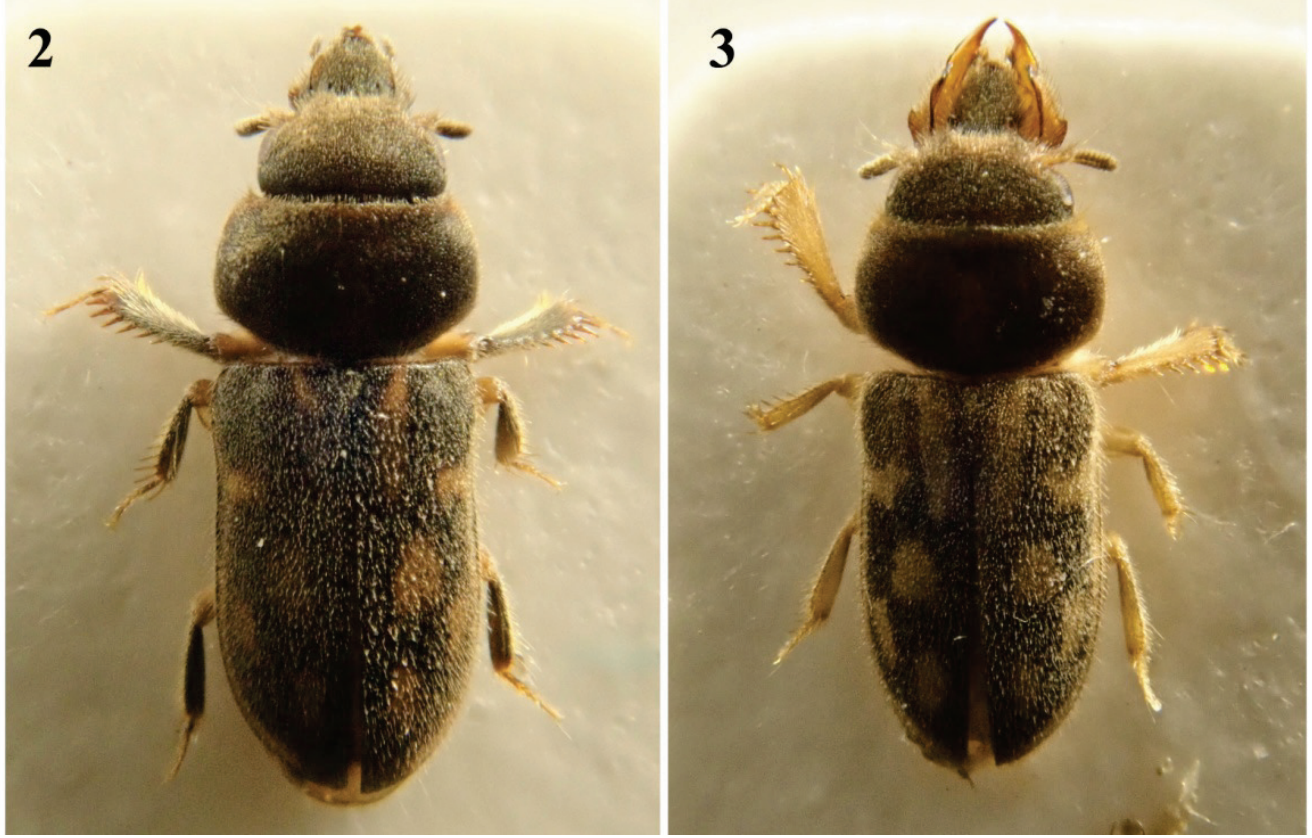

Figs 2-3. Heterocerus tibesticola Charpentier, 1964: 2 - normal male (Gumara River), 3 - male with hypertrophic mandibules (Rib River).
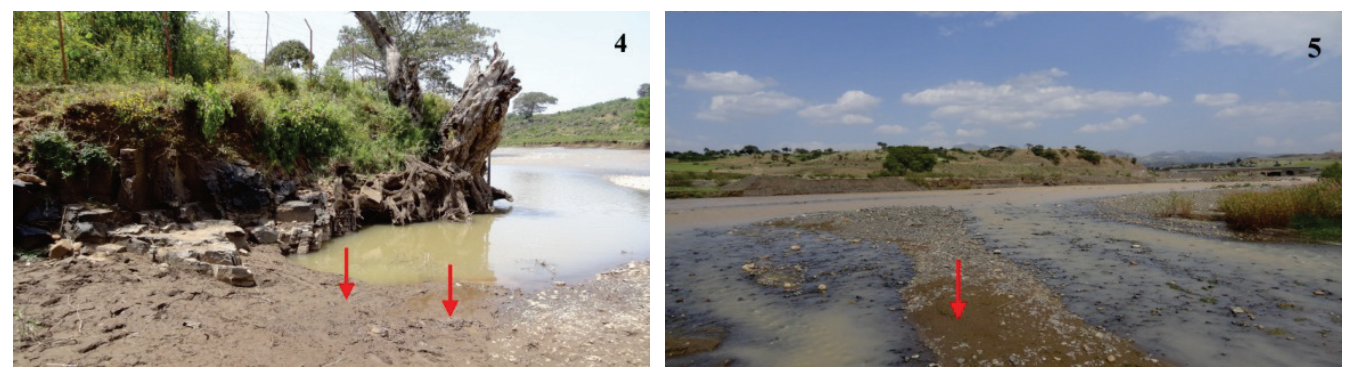

Figs 4-5. Habitats of Heterocerus spp. in Ethiopia (Amhara region). 4 - Gumara River (Heterocerus atroincertus and Heterocerus tibesticola); 5 - Rib River (Heterocerus tibesticola).

\section{ACKNOWLEDGEMENTS}

The studies of the first author were carried out under the framework of the Russian state research project No. AAAA-A17-117030310210-3. The authors are grateful for help in a work to Alessandro Mascagni (Firenze, Italy). We are also grateful for help in field work to Fedor N. Shkil and Andrey A. Darkov (A.N. Severtsov Institute of Ecology and Evolution, Russian Academy of Sciences, Moscow, Russia), and coordination of work of the Joint Ethio-Russian Biological Expedition, which organized our research. 


\section{REFERENCES}

ChARPEnTIER R. 1964. Heterocerus tibesticola, spec. nov. (Coleoptera: Heteroceridae) from Chad and Yemen. Bulletin de l'Institut Française d'Afrique Noire. Série A, Sciences Naturelles 26: 580-584.

Charpentier R. 1965. A monograph of the family Heteroceridae of the Ethiopian Region. In: HANSTROM B., BrinCK P. \& RUdEBECK G. (eds), South African Animal Life. II. Result of the Lund University expedition in 1950-1951. Vol. XI. Swedish Natural Science Research Council; Stockholm - VA: 215-343.

KING J.G. \& LAGO P.K. 2012. The variegated mudloving beetles (Coleoptera: Heteroceridae) of Mississippi and Alabama, with discussion and keys to the species occurring in the south eastern United States. Insecta Mundi 275: $1-53$.

MAMiTZA R. 1930. Ein neuer Heterocerus aus Abessinien. Entomologisches Nachrichtenblatt 4: 85-86.

MASCAGNI A. 1988. Heterocerus hardei new species from Ethiopia (Coleoptera: Heteroceridae). Tropical Zoology 1: 91-94. DOI: 10.1080/03946975.1988.10539406

MASCAGNI A. 1995. Heteroceridae: Check list of the Heteroceridae of China and neighbouring countries, and description of two new species (Coleoptera), pp. 341-348. In: JÄCH M. A. \& JI L. (eds), Water Beetles of China. Vol. 1. Zoologisch-Botanische Gesellschaft in Österreich and Wiener Coleopterologenverein, Wien, $410 \mathrm{pp}$.

Mascagni A. 2012. Su alcuni Eteroceridi dello Swedish Museum of Natural History of Stockholm (Coleoptera, Heteroceridae). Onychium 9: 73-77.

MAsCAGni A. \& MonTE C. 2003. Contributo alla conoscenza degli Heteroceridae dell'Angola, Camerun, Central African Republic, Congo, Eritrea, Ethiopia, Kenya, Somalia, Sudan, Uganda, Zaire (Coleoptera). Opuscula zoologica fluminensia 208: 1-14.

MASCAGNi A. \& MONTE C. 2009. Secondo aggiornamento alla checklist degli Heteroceridae della regione afrotropicale (Coleoptera, Heteroceridae). Onychium 7: 61-72.

SAZHNEV A.S. 2018. Checklist of the Heteroceridae (Insecta, Coleoptera) of the World. Draft version 26.07.2018. Available at https://www.researchgate.net/publication/326690724 (25 Dec 2018).

TAŞAR G.E. 2014. A Contribution to the knowledge of Turkish Dryopidae, Elmidae and Heteroceridae (Coleoptera: Byrrhoidea) Fauna. Archives of Biological Sciences, Belgrade 66: 1473-1478. DOI:10.2298/ABS1404473T

TAŞAR G.E. \& MASCAGNi A. 2014. Checklist of Heteroceridae (Coleoptera) of Turkey. Pakistan Journal of Zoology 46: $1685-1690$.

VAnin S. A., Costa C., IDE S. \& Beutel R. G. 2016. Heteroceridae MacLeay, 1825, pp. 612-615. In: Beutel R. G. \& Leschen R. A. B. (eds), Handbook of zoology. Volume IV Arthropoda, Part 38. Coleoptera, Beetles. Volume 1: Morphology and Systematics (Archostemata, Adephaga, Myxophaga, Polyphaga partim). Walter de Gruyter, Berlin, 684 pp.

\section{STRESZCZENIE}

\section{[Nowe stwierdzenia Heteroceridae (Coleoptera) z Etiopii]}

W pracy podano nowe stwierdzenia faunistyczne dotyczące Heteroceridae $\mathrm{z}$ Etiopii w regionie Amhara, znad rzeki Gumara i rzeki Rib. Dwa nowo wykazane gatunki: Heterocerus atroincertus Charpentier, 1965 and Heterocerus tibesticola Charpentier, 1964 zwiększają liczbę gatunków chrząszczy różnorożkowatych w faunie etiopskiej do siedmiu, jakkolwiek dotychczasowe dane z sąsiednich krajów sugerują możliwość znalezienie w Etiopii co najmniej dziewięciu dalszych gatunków. 